\title{
Analisis Pemecahan Masalah Matematika Higher Order Thinking Ditinjau Dari Gaya Kognitif Siswa
}

\author{
Ainun Maghfiroh ${ }^{1^{*}}$, Restu Ria Wantika ${ }^{2}$ \\ ${ }^{1}$ Pendidikan Matematika, Universitas PGRI Adi Buana, Surabaya, Indonesia; \\ *ainunmaghfiroh57@gmail.com \\ ${ }^{2}$ Pendidikan Matematika, Universitas PGRI Adi Buana, Surabaya, Indonesia; \\ restu@unipasby.ac.id
}

\begin{abstract}
Abstrak. Penelitian ini bertujuan untuk mendeskripsikan pemecahan masalah Higher Order Thinking yang ditinjau dari gaya kognitif siswa. Penelitian ini merupakan penelitian kualitatif. Peneliti menggunakan data hasil GEFT (Group Embedded Figure Test), data hasil penyelesaian soal - soal berpikir tingkat tinggi (Higher Order Thinking) dan juga data hasil wawancara pada dua subjek siswa SMA Negeri 1 Taman. Dua subjek tersebut terdiri dari satu subjek dengan gaya kognitif field independent dan juga satu subjek dengan gaya kognitif field dependent. Selanjutnya data yang diperoleh dianalisis dengan menggunakan empat indikator pemecahan masalah Polya. Dari penelitian yang telah dilakukan menujukkan hasil penelitian sebagai berikut: (1) Siswa dengan gaya kognitif field independent dinyatakan mampu pada seluruh indikator pemecahan masalah Polya pada masalah matematika higher order thinking dengan tingkatan kognitif analyze (menganalisis), evaluate (mengevaluasi) dan create (menciptakan). (2) Siswa dengan gaya kognitif field dependent dinyatakan mampu pada seluruh indikator pemecahan masalah Polya pada masalah matematika higher order thinking dengan tingkatan kognitif analyze (menganalisis) dan create (menciptakan). Akan tetapi kurang mampu pada indikator merencanakan atau merancang strategi pemecahan masalah, indikator melaksanakan perhitungan serta indikator memeriksa kembali kebenaran hasil atau solusi pada tingkatan kognitif evaluate (mengevaluasi).
\end{abstract}

Kata Kunci: field dependent, field independent, pemecahan masalah Polya.

\begin{abstract}
This research was designed to describe the Problem Solving of HigherOrder Thinking in terms of Student Cognitive Style. This is a qualitative research. Researchers used data from the GEFT (Group Embedded Figure Test), data from the completion of high-level thinking questions and interviews on two subjects of students at State High School 1 Taman. The two subjects consisted of one subject by independent field cognitive style and the other one by dependent field cognitive style. Than the data obtained were resolved using by four indicators of Polya problem solving. The results showed that: (1) Students with independent-field cognitive style was declared capable of all Polya problem solving indicators on higher-orderthinking mathematical problem with cognitive levels analyze, evaluate and create. (2) Students with dependent-field cognitive style was declared capable of all Polya
\end{abstract}


problem solving indicators on higher-order-thinking mathematical problem with cognitive levels analyze and create. But less able to understanding indicators of planning or designing problem solving strategies, indicators of performing calculations and indicators of checking again the truth of the results or solutions with cognitive levels evaluate.

Keywords: field dependent, field independent, Polya's problem solving.

\section{Pendahuluan}

Pendidikan merupakan penyesuaian hidup yang diberikan kepada semua orang agar dapat hidup secara demokratis, yang memberikan kepuasan kepada diri sendiri dan menguntungkan masyarakat. Pada dasarnya, untuk meningkatkan potensi nilai sumber daya manusia suatu bangsa salah satunya dengan melalui pendidikan. Pada industri 4.0 seperti saat ini perkembangan teknologi pendidikan semakin maju, hal itu menunjukkan bahwa Indonesia harus mengikuti perkembangan pendidikan. Oleh sebab itu, pendidikan tidaklah bisa jika dipisahkan dengan pelajaran matematika, karena implementasi pembelajaran matematika ialah untuk membantu manusia menyelesaikan masalah - masalah sosial. Menurut Freudental (Sriyanto, 2017) Matematika merupakan aktivitas manusia (human activities) yang berkaitan dengan realitas atau kenyataan.

Hasil studi TIMSS (Trends in International Mathematics and Science Study) menjelaskan jika dalam beberapa aspek kemampuan matematika siswa Indonesia berada pada tingkatan rangking yang sangat rendah. Menurut (Nurrakhmi \& Dr. Agung Lukito, 2014) salah satu cara untuk memperbaiki kemampuan pemecahan masalah peserta didik dengan dilakukannya perbaikan - perbaikan proses pembelajaran dikelas. Negara Indonesia memerlukan perubahan untuk bersaing dengan negara - negara lain dalam pengembangan ilmu sebagai sarana pemecahan masalah kontekstual. Salah satunya dengan cara melatih dan mengarahkan kemampuan siswa berpikir dalam tingkatan yang tinggi atau HOT (Higher Order Thinking) dalam menghadapi suatu pemecahan masalah. Wena (2009) menjelaskan jika pemecahan masalah merupakan suatu proses hubungan dari aturan - aturan yang berlaku dapat diterapkan pada suatu kondisi yang baru. Siswa dikatakan mampu berpikir tingkat tinggi atau HOT (Higher Order Thingking) apabila telah memenuhi tiga aspek dimensi kawasan kognitif pada taksonomi Bloom. Menurut (Husamah, 2018) taksonomi Bloom adalah tingkatan yang dapat mengelompokkan kemampuan berpikir dimulai dari tingkat rendah hingga tingkat tinggi. Tingkatan tersebut meliputi: pengetahuan, pemahaman, aplikasi, analisis, evaluasi dan mencipta. Kemampuan dalam Copyright (C) 2020

\section{Buana Matematika :}

Jurnal Ilmiah Matematika dan Pendidikan Matematika 
berpikir tingkat tinggi atau HOT (Higher Order Thinking) mengharuskan siswa dapat menganalisis dalam memecahkan masalah matematika, mengevaluasi suatu permasalahan matematika, serta mampu menciptakan atau mengkreasikan suatu cara pemecahan masalah pada kehidupan sehari - hari dengan kemampuan matematisnya. Namun tidak semua siswa menganggap matematika pelajaran yang mudah untuk dipahami. Oleh sebab itu, siswa akan melalui suatu proses kegiatan untuk memecahkan masalah tersebut. Salah satu langkah pemecahan masalah adalah langka menurut Polya (Sutarto Hadi, 2014) yang terdiri dari empat langkah, yaitu: (1) memahami masalah, (2) menentukan rencana strategi pemecahan masalah, (3) menyelesaikan strategi penyelesaian masalah, dan (4) memeriksa kembali jawaban yang diperoleh.

Dalam proses pembentukan gagasan maupun pengetahuan untuk memecahkan masalah yang ada pada matematika, terdapat proses mental pada setiap orang (Nurrakhmi \& Dr. Agung Lukito, 2014). Kognisi adalah sebuah istilah yang merujuk pada sebuah proses mental yang terlibat pada sebuah aktivitas untuk mendapatkan pengetahuan dan pemahaman, termasuk juga berpikir, mengetahui, mengingat, menilai, dan memecahkan masalah (Kuswana, 2011). Dalam memecahkan suatu masalah pada tingkat tinggi, setiap orang pastilah memiliki kemampuan berpikir yang berbeda beda. Perbedaan individu satu dengan yang lain dalam cara mengolah dan menyusun informasi biasa disebut sebagai gaya kognitif (Selameto, 2010)

Menurut (Selameto, 2010) dalam bukunya menjelaskan jika gaya kognitif diartikan sebagai suatu sikap, pilihan, atau strategi yang dapat menunjukkan cara unik dari seseorang dalam menerima, mengingat, berpikir, serta memecahkan masalah. Ada berbagai macam gaya kognitif, diantaranya ialah: field independent - field dependent, impulsif - reflektif, perseptif - reseptif dan sistematis - intuitif. Banyak peneliti yang telah mempelajari gaya kognitif, salah satunya ialah gaya kognitif "field independent" dan "field dependent". Menurut (Desmita, 2012) field independent - field dependent adalah gaya kognitif yang menunjukkan cara menganalisis atau cara melihat sudut pandang seseorang didalam lingkungan sekitarnya. Perbedaan kedua gaya kognitif tersebut terletak dari cara pandang seseorang terhadap suatu permasalahan. Selain itu, gaya kognitif ini juga disebut sebagai salah satu objek penentu kemampuan pemecahan masalah yang dilakukan oleh siswa. Jika seorang siswa memiliki gaya kognitif field independent, maka siswa tersebut akan cenderung mendeskripsikan suatu gambaran lepas dari latar belakang gambaran tersebut dengan kata lain siswa dapat mengarang bebas, siswa

Copyright (C) 2020

Buana Matematika :

Jurnal Ilmiah Matematika dan Pendidikan Matematika 
tersebut juga lebih mudah dalam membedakan objek dari lingkungan yang ada disekitarnya. Sedangkan jika seorang siswa memiliki gaya kognitif field dependent akan cenderung menerima suatu gambaran secara global, siswa tersebut juga lebih sulit dalam membedakan objek dilingkungan sekitarnya. Sehingga karakteristik dari gaya kognitif field independent dan field dependent tersebut akan sangat cocok apabila digunakan pada penelitian yang akan melibatkan proses - proses berpikir dalam suatu pemecahan masalah matematika (Ngilawajan, 2013) Oleh sebab itu, peneliti menggunakan gaya kognitif field independent dan juga gaya kognitif field dependent untuk mengetahui proses Higher Order Thinking Skills terhadap pemecahan masalah matematika.

Geometri merupakan salah satu materi yang diajaran dalam matematika. Menurut (Rohimah et al., 2016) ada banyak konsep - konsep matematika jika dideskripsikan menggunakan bahasa geometri akan lebih mudah dipahami oleh siswa, sehingga materi ini sangat penting untuk dikuasai karena menyangkut hal - hal kontekstual yang ada pada kehidupan sehari - hari. Misalnya, saat melakukan penghitungan luas atau keliling tanah dan masih banyak lagi. Peneliti memilih materi Geometri Transformasi karena pada pemilihan subjek field independent dan field dependent siswa mengerjakan GEFT (Group Embedded Figure Test). GEFT yang diterima siswa berupa soal bangun datar geometri. Apabila siswa tidak mampu dalam memecahkan masalah pada materi geometri, maka akan berpengaruh pada materi - materi matematika yang lainnya. Sehingga akan berdampak pada kurangnya siswa dalam kemampuan pemecahan masalah matematika.

Pada penelitian ini, peneliti telah menentukan pilihan SMA Negeri 1 Taman sebagai tempat penelitian. Hal ini dikarenakan SMA Negeri 1 Taman merupakan salah satu sekolah yang cukup baik di Kecamatan Taman, Sidoarjo. Peneliti melakukan observasi secara langsung selama praktik Magang III di SMA Negeri 1 Taman pada tanggal 16 September 2019 sampai tanggal 16 November 2019, bahwa tidak semua siswa mampu dalam indikator kemampuan pemecahan masalah. Siswa lebih condong terhadap soal perhitungan saja, tidak dengan soal kontekstual. Hal ini dapat terlihat dari indikator memahami masalah yang dapat dilalui siswa dengan mudah. Akan tetapi pada indikator merencanakan atau merancang strategi pemecahan, melaksanakan perhitungan serta memeriksa kembali kebenaran hasil atau solusi, tidak semua siswa dapat melaluinya. Hal ini terlihat saat melakukan perhitungan banyak siswa yang masih melakukan kesalahan.

Copyright (C) 2020

Buana Matematika :

Jurnal Ilmiah Matematika dan Pendidikan Matematika 


\section{Metode}

Dalam penelitian ini peneliti menggunakan penelitian yang berdasarkan tingkatan kealamiahan (natural setting). Tingkatan kealamiahan suatu penelitian dapat dikelompokkan menjadi tiga metode yaitu: metode penelitian eksperimen, metode penelitian survey dan dan metode penelitian naturalistik (Sugiyono, 2018). Sugiyono menjelaskan jika metode penelitian survey dan juga metode penelitian eksperimen termasuk dalam jenis penelitian kuantitatif, sedangkan metode penelitian naturalistik termasuk dalam penelitian kualitatif. Sehingga pada penelitian ini, peneliti akan menggunakan metode penelitian kualitatif. Penelitian kualitatif merupakan penelitian yang mendeskripsikan suatu objek alami dengan menggunakan bentuk kata - kata. Penelitian ini menggunakan karakteristik penelitian deskriptif yang mendeskripsikan gambaran suatu peristiwa atau kejadian, dan juga masalah - masalah yang terjadi pada saat dilakukannya penelitian.

Data pada penelitian ini ialah siswa kelas XI Mipa 5 SMA Negeri 1 Taman. Sebagai subjek penelitian, peneliti membagi siswa berdasarkan gaya kognitif field independent dan gaya kognitif field dependent dengan memberi siswa sebuah tes GEFT (Group Embedded Figure Test). Setelah melalui proses pemilihan subjek, diperoleh dua siswa sebagai subjek penelitian ini. Satu orang siswa dengan gaya kognitif field independent dan satu orang siswa dengan gaya kognitif field dependent.

Instrumen utama pada penelitian kualitatif adalah peneliti itu sendiri. Untuk melengkapi data penelitian, peneliti mengembangkan instrumen pendukung yaitu sebagai berikut:

\section{Test GEFT}

Group Embedded Figure Test atau yang biasa disebut GEFT adalah sebuah tes yang digunakan untuk mengidentifikasikan gaya kognitif yang dikemukakan oleh Herman A. Witkin. Tes ini terdiri dari 25 butir soal dengan 3 tahap pengerjaan, tahap pertama siswa mengerjakan 7 butir soal sebagai latihan dengan waktu 5 menit, tahap kedua siswa mengerjakan 9 butir soal dalam waktu 7 menit dan tahap ketiga siswa mengerjakan 9 butir soal dengan waktu 7 menit. Tahap kedua dan juga ketiga digunakan sebagai hasil tes GEFT.

\section{Tes Matematika}

Tes digunakan untuk mendapatkan nilai kemampuan berpikir tingkat tinggi pada pemecahan masalah matematis siswa. Tes dilakukan setelah siswa dipilih berdasarkan gaya kognitifnya. Tes yang akan digunakan pada

Copyright (C) 2020

Buana Matematika :

Jurnal Ilmiah Matematika dan Pendidikan Matematika 
penelitian adalah tes uraian dari soal berpikir tingkat tinggi atau HOT (Higher Order Thinking) yang terdiri dari indikator menganalisis (analyze), mengevaluasi (evaluate) dan menciptakan (create) berdasarkan empat langkah pemecahan masalah Polya meliputi: memahami suatu masalah, merencanakan atau merancanag strategi pemecahan masalah, melaksanakan perhitungan dan memeriksa kembali hasil atau solusi.

\section{Wawancara}

Peneliti menggunakan pedoman wawancara yang telah divalidasi sebagai acuan selama wawancara berlangsung. Wawancara dilakukan pada dua subjek penelitian yang telah dipilih berdasarkan kriteria penentuan subjek. Wawancara dilakukan dengan menggunakan alat perekam atau audio recorder sehingga dapat menunjukkan keabsahannya. Wawancara dilakukan secara bergantian, sehingga peneliti dapat dengan mudah menyimpulkan hasil informasi terutama pada kemampuan pemecahan masalah pada soal berpikir tingkat tinggi atau HOT (Higher Order Thinking) yang telah siswa kerjakan.

Penelitian ini menggunakan teknik analisis yang dikemukakan oleh Miles dan Huberman. Setiap data akan dianalisis melalui tiga tahapan, yaitu tahap reduksi data, tahap penyajian data dan juga tahap penarikan kesimpulan.

\section{Hasil dan Pembahasan}

Higher Order Thinking (HOT) memiliki hubungan yang sangat erat kaitannya dengan gaya kognitif field independent - field dependent, hal ini diperkuat dengan adanya penelitian - penelitian yang terdahulu, salah satunya ialah penelitian dari (Ngilawajan, 2013) yang meneliti tentang Proses Berpikir Siswa SMA dalam memecahkan masalah matematika materi turunan ditinjau dari Gaya Field Independent dan Field Dependent. Berdasarkan hasil penelitian menunjukkan jika terdapat perbedaan yang signifikan terhadap kedua subjek pada langkah memahami masalah, yaitu subjek FI memahami masalah lebih baik bila dibandingkan dengan subjek FD. Selain itu, subjek FI menunjukkan pemahaman yang baik terhadap konsep turunan bila dibandingkan dengan FD.

Sedangkan pada pembahasan hasil penelitian ini, pemecahan masalah Higher Order Thinking mengacu pada tipe gaya kognitif field independent dan juga gaya kognitif field dependent siswa. Subjek field independent terdiri dari satu siswa dan subjek field dependent terdiri dari satu siswa dengan soal pada level kognitif Analyze (menganalisis) kategori organizing (mengorganisasikan), Evaluate (mengevaluasi) kategori checking (memeriksa) dan Create Copyright (C) 2020

\section{Buana Matematika :}

Jurnal Ilmiah Matematika dan Pendidikan Matematika 
(menciptakan) kategori producing (memproduksi). Soal yang telah diselesaikan kemudian dianalisis dengan empat indikator pemecahan masalah Polya, dimana siswa diharapkan mampu dalam: memahami masalah, merancang atau merencanakan strategi pemecahan masalah, melakankan perhitungan serta dapat memeriksa kembali kebenaran hasil atau solusi.

Setelah itu data dianalisis, hasil penyelesaian masalah Higher Order Thinking dan wawancara dilakukan dengan menggunakan tahap reduksi, tahap penyajian data dan juga tahap pengambilan kesimpulan. Selanjutnya dilakukan triangulasi untuk mengetahui keabsahan data yang telah diperoleh. Triangulasi dilakukan pada masing - masing subjek diperoleh deskripsi penyelesaian masalah Higher Order Thinking seperti pada subbab sebelumnya. Deskripsi analisis data yang dilakukan pada masing - masing subjek dengan hasil sebagai berikut:

\section{Subjek field independent}

Subjek field independent terdiri dari satu siswa, berikut merupakan hasil penyelesaian soal higher order thinking pada subjek field independent:

Pada indikator memahami masalah dari soal higher order thinking dengan indikator analyze (menganalisis), evaluate (mengevaluasi) dan create (menciptakan), subjek field independent mampu untuk memahami soal dengan sangat baik. Hal ini dikarenakan subjek dapat mengetahui informasi dan permasalahan dengan tepat dan benar serta dapat mengungkapkan informasi berada pada soal dengan jelas. Subjek dapat mengidentifikasi data yang diberikan untuk menyelesaikan masalah.

Pada indikator merencanakan atau merancang strategi pemecahan masalah dari soal higher order thinking dengan indikator analyze (menganalisis), evaluate (mengevaluasi) dan create (menciptakan), subjek field independent dapat menentukan gambaran permasalahan yang ada pada soal dengan sangat baik. Subjek juga mampu menggunkan rumus mana yang tepat digunakan untuk menyelesaikan permasalahan soal.

Pada indikator melaksanakan perhitungan dari soal higher order thinking dengan indikator analyze (menganalisis), evaluate (mengevaluasi) dan create (menciptakan), subjek field independent dapat mengoperasikan proses penyelesaian dengan sangat baik. Hal ini dikarenakan subjek dapat menyelesaikan permasalahan sesuai dengan rencana strategi penyelesaian

Copyright (C) 2020

Buana Matematika :

Jurnal Ilmiah Matematika dan Pendidikan Matematika 
yang diinginkan subjek serta mendapatkan hasil perhitungan yang benar dan tepat.

Pada indikator memeriksa kembali kebenaran hasil atau solusi dari soal higher order thinking dengan indikator analyze (menganalisis), evaluate (mengevaluasi) dan create (menciptakan), subjek field independent dapat melaksanakan dengan baik. Subjek melakukan pengecekan ulang pada setiap soal serta dapat meyakinkan diri bahwa hasil penyelesaiannya sesuai dengan apa yang ada pada soal.

Berdasarkan hasil pembahasan tersebut, siswa dengan gaya kognitif field independent dapat dikatakan mampu memahami masalah yang ada, karena dapat mengetahui informasi dan permasalahan dengan tepat dan benar yang berada pada soal dan mampu mengungkapkan informasi tersebut dengan jelas. Kemudian siswa dengan gaya kognitif field independent mampu merencanakan atau merancang strategi pemecahan masalah, karena dapat menentukan gambaran permasalahan serta mampu menggunkan rumus yang tepat. Selain itu siswa dengan gaya kognitif field independent mampu menyelesaikan permasalahan dan perhitungan dengan baik sesuai dengan strategi penyelesaian dengan tepat. Siswa field independent juga mampu memeriksa kembali kebenaran hasil atau solusi, karena setelah selesai melakukan perhitungan siswa melakukan perhitungan ulang untuk mengecek perhitungannya.

\section{Subjek field dependent}

Subjek field independent terdiri dari satu siswa, berikut merupakan hasil penyelesaian soal higher order thinking pada subjek field independent:

Pada indikator memahami masalah dari soal higher order thinking dengan indikator analyze (menganalisis), evaluate (mengevaluasi) dan create (menciptakan), subjek field dependent mampu untuk memahami soal dengan sangat baik. Hal ini dikarenakan subjek dapat mengetahui informasi dan permasalahan dengan tepat dan benar yang berada pada soal. Subjek dapat mengidentifikasi data yang diberikan untuk menyelesaikan masalah.

Pada indikator merencanakan atau merancang strategi pemecahan masalah dari soal higher order thinking dengan indikator analyze (menganalisis) dan create (menciptakan), subjek field dependent dapat menentukan gambaran permasalahan yang ada pada soal dengan sangat baik. Subjek juga mampu menggunkan rumus mana yang tepat digunakan untuk menyelesaikan Copyright (C) 2020

\section{Buana Matematika :}

Jurnal Ilmiah Matematika dan Pendidikan Matematika 
permasalahan soal. Akan tetapi pada soal higher order thinking dengan indikator evaluate (mengevaluasi), subjek masih kurang mampu dalam merencanakan atau merancang strategi pemecahan masalah karena subjek tidak dapat memutuskan rumus mana yang akan digunakan dengan tepat.

Pada indikator melaksanakan perhitungan dari soal higher order thinking dengan indikator analyze (menganalisis) create (menciptakan), subjek field dependent dapat mengoperasikan proses penyelesaian dengan sangat baik. Hal ini dikarenakan subjek dapat menyelesaikan permasalahan sesuai dengan rencana strategi penyelesaian yang diinginkan serta hasil yang tepat dan benar. Akan tetapi, pada soal higher order thinking dengan indikator evaluate (mengevaluasi), subjek tidak mampu melaksanakan perhitungan dan tidak mampu menyelesaikan masalah karena keterbatasan waktu dan ketidakmampuannya dalam menentukan rumus yang akan dipilih.

Pada indikator memeriksa kembali kebenaran hasil atau solusi dari soal higher order thinking dengan indikator analyze (menganalisis) dan create (menciptakan), subjek field dependent dapat melaksanakan dengan baik. Subjek melakukan pengecekan ulang pada setiap soal serta dapat meyakinkan diri bahwa hasil penyelesaiannya telah sesuai dengan pertanyaan yang ada pada soal. Akan tetapi, pada soal higher order thinking dengan indikator evaluate (mengevaluasi), subjek tidak mampu memeriksa kembali kebenaran hasil dikarenakan subjek tidak melakukan operasi hitung pada soal nomor tiga.

Berdasarkan hasil pembahasan tersebut, siswa dengan gaya kognitif field dependent dapat dikatakan mampu memahami masalah, karena dapat mengetahui informasi dan permasalahan dengan tepat dan benar yang berada pada soal dan mampu mengungkapkan informasi tersebut dengan jelas. Akan tetapi tidak cukup mampu merencanakan atau merancang strategi pemecahan masalah, karena tidak dapat menentukan gambaran permasalahan serta tidak mampu menentukan rumus yang tepat pada setiap masalah. Selain itu siswa dengan gaya kognitif field dependent tidak mampu menyelesaikan permasalahan dan perhitungan dengan baik sesuai dengan strategi penyelesaian dengan tepat serta tidak mampu memeriksa kembali kebenaran hasil atau solusi pada setiap pokok bahasan soal cerita.

\section{Simpulan}

Dari pembahasan hasil penelitian yang sudah dikemukakan oleh peneliti, maka berikut ini adalah deskripsi dari pemecahan masalah matematika Higher Order Thinking ditinjau dari gaya kogitif siswa dengan field independent

Copyright (C) 2020

Buana Matematika :

Jurnal Ilmiah Matematika dan Pendidikan Matematika 
dinyatakan mampu pada seluruh indikator pemecahan masalah Polya pada masalah matematika higher order thinking dengan tingkatan kognitif analyze (menganalisis), evaluate (mengevaluasi) dan create (menciptakan). Sementara untuk siswa field dependent dinyatakan mampu pada seluruh indikator pemecahan masalah Polya pada masalah matematika higher order thinking dengan tingkatan kognitif analyze (menganalisis) dan create (menciptakan). Akan tetapi kurang mampu pada indikator merencanakan atau merancang strategi pemecahan masalah, indikator melaksanakan perhitungan serta indikator memeriksa kembali kebenaran hasil atau solusi pada tingkatan kognitif evaluate (mengevaluasi).

\section{Daftar Pustaka}

Desmita. (2012). Psikologi Perkembangan. Bandung: PT. Remaja Rosdakarya.

Husamah. (2018). Belajar E Pembelajaran. Malang: Universitas Muhammadiyah Malang.

Kuswana, W. (2011). Taksonomi Berpikir. Bandung: PT. Remaja Rosdakarya.

Ngilawajan, D. A. (2013). PROSES BERPIKIR SISWA SMA DALAM FIELD INDEPENDENT DAN FIELD DEPENDENT. 2(1), 71-83.

Nurrakhmi, R. Z. F., \& Dr. Agung Lukito, M. S. (2014). Profil Intuisi Siswa SMA dalam Memecahkan Masalah Turunan Ditinjau Dari Gaya Kognitif Field Dependent dan Field Independent. 3(3), 208-214.

Rohimah, I., Nursuprianah, I., Matematika, T., Syekh, I., Cirebon, N., \& Sunyaragi, B. (2016). PENGARUH PEMAHAMAN KONSEP GEOMETRI TERHADAP KEMAMPUAN SISWA DALAM MENYELESAIKAN SOALSOAL BIDANG DATAR (Studi Kasus Kelas VII di SMP Negeri 1 Cidahu Kabupaten Kuningan) Iim. 5(1).

Selameto. (2010). Belajar dan Faktor Faktor yang mempengaruhinya. Jakarta: Rineka Cipta.

Sriyanto. (2017). Mengobarkan Api Matematika. Sukabumi: Cv. Jejak.

Sugiyono. (2018). Metode Penelitian Kuantitatif, Kualutatif, dan RED. Bandung: Alfabeta.

Copyright (C) 2020

Buana Matematika :

Jurnal Ilmiah Matematika dan Pendidikan Matematika 
Sutarto Hadi, R. (2014). METODE PEMECAHAN MASALAH MENURUT POLYA UNTUK MENGEMBANGKAN DI SEKOLAH MENENGAH PERTAMA Sutarto Hadi, Radiyatul. 2, 53-61.

\section{Riwayat Hidup Penulis \\ Ainun Maghfiroh}

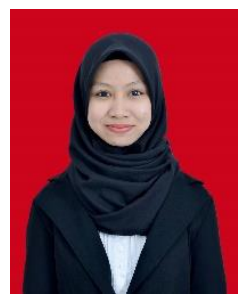

Lahir di Kota Gresik, 15 Maret 1998. Penulis adalah mahasiswa aktif yang sedang menempuh Studi S1 Pendidikan Matematika di Universitas PGRI Adi Buana Surabaya.

\section{Restu Ria Wantika}

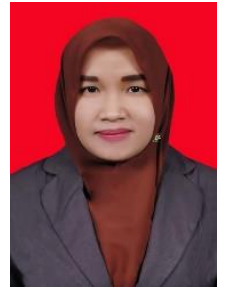

Lahir di Kota Surabaya, 22 November 1989. Penulis adalah pengajar pada S1 Program Studi Pendidikan Matematika, Fakultas Sains dan Teknologi, Universitas PGRI Adi Buana Surabaya. Menyelesaikan Studi S1 pada tahun 2011 Pendidikan Matematika Universitas Negeri Surabaya. Selanjutnya melanjutkan Studi S2 Matematika Institut Teknologi Sepuluh Nopember Surabaya, lulus pada tahun 2015. Dan saat ini sedang menempuh Studi S3 Pendidikan Matematika Universitas Negeri Surabaya. Penulis juga berhasil meraih hibah dari Kemenristek Dikti tahun 2018 pada Skema Dosen Pemula. 
Jurnal Ilmiah Matematika dan Pendidikan Matematika Vol. 10 No. 2 (2020)

Copyright (C) 2020

Buana Matematika :

Jurnal Ilmiah Matematika dan Pendidikan Matematika 